\title{
NO VISION TO VISION IN A CASE OF BILATERAL RETROBULBAR NEURITIS
}

Nithisha T. $\mathrm{M}^{1}$, L. Nanda를 Shivakumar $\mathrm{M}^{3}$, Chenchi Reddy $\mathrm{M}^{4}$

\section{HOW TO CITE THIS ARTICLE:}

Nithisha T. M, L. Nanda, Shivakumar M, Chenchi Reddy M. "No Vision to Vision in a Case of Bilateral Retrobulbar Neuritis". Journal of Evolution of Medical and Dental Sciences 2014; Vol. 3, Issue 12, March 24;

Page: 3194-3198, DOI: 10.14260/jemds/2014/2265

ABSTRACT: Presenting here, a rare case of bilateral retro bulbar neuritis in a 50 year old male patient who has no perception of light for 1 day. Patient was investigated and causes of optic neuritis were ruled out and finally he was treated with systemic steroids and visual outcome was good from no perception of light to $6 / 12 p$ aided vision in right eye and $6 / 18 p$ in left eye.

KEYWORDS: Optic neuritis, Retro bulbar neuritis, Systemic steroids.

INTRODUCTION: Retro bulbar neuritis is a type of optic neuritis in which optic nerve gets inflamed from back of the eye to brain. There will be no ophthalmoscopic changes in retro bulbar neuritis, unless the lesion is near to lamina cribrosa, so diagnosis is based on symptoms and investigations alone. ${ }^{1}$

CASE REPORT: A 50 year old male patient presented to our OPD with sudden painless progressive loss of vision in both eyes. It started in the left eye 10 days back and after 5 days the right eye was also affected. He was treated with native medication for 10 days and came to our hospital. No history of trauma, seeing flashes of light, floaters, loss of visual field, change in size and shape of objects, diplopia, scalp tenderness. No history of diabetes mellitus, hypertension, asthma, tuberculosis, or any other systemic illness. He is a chronic smoker since 25 years (3 cigarettes per day), and not an alcoholic. No history of any long term drug usage. No history of spectacles usage or any surgeries in the eye.

\begin{tabular}{|c|c|c|}
\hline Ocular examination & Right eye & Left eye \\
\hline Unaided visual acuity & $\begin{array}{l}\text { PL present; } \\
\text { PR inaccurate }\end{array}$ & PL absent \\
\hline External appearance & Normal & Normal \\
\hline $\begin{array}{l}\text { Slit lamp examination } \\
\text { Lids } \\
\text { Conjunctiva } \\
\text { Cornea } \\
\text { Anterior chamber } \\
\text { Pupils } \\
\text { Lens }\end{array}$ & $\begin{array}{l}\text { Normal } \\
\text { Normal } \\
\text { Clear } \\
\text { Deep and quiet } \\
\text { Round, regular and } \\
\text { reacting to light } \\
\text { Normal }\end{array}$ & $\begin{array}{l}\text { Normal } \\
\text { Normal } \\
\text { Clear } \\
\text { Deep and quiet } \\
\text { Relative Afferent Pupillary } \\
\text { Defect (RAPD) present } \\
\text { Normal }\end{array}$ \\
\hline
\end{tabular}




\section{CASE REPORT}

\begin{tabular}{|c|c|c|}
\hline $\begin{array}{l}\text { Fundus examination } \\
\text { Optic disc } \\
\text { Size } \\
\text { Shape } \\
\text { Color } \\
\quad \text { Margins } \\
\text { Cup: Disc } \\
\text { Vessels } \\
\text { Macula } \\
\text { Background }\end{array}$ & $\begin{array}{l}\text { Normal } \\
\text { Round } \\
\text { Pink } \\
\text { Well-defined } \\
0.3 \\
\text { Mild arteriolar narrowing + } \\
\text { Foveal Reflex + } \\
\text { Normal }\end{array}$ & $\begin{array}{l}\text { Normal } \\
\text { Round } \\
\text { Pink } \\
\text { Well-defined } \\
0.3 \\
\text { Mild arteriolar narrowing + } \\
\text { Foveal Reflex+ } \\
\text { Normal }\end{array}$ \\
\hline & & 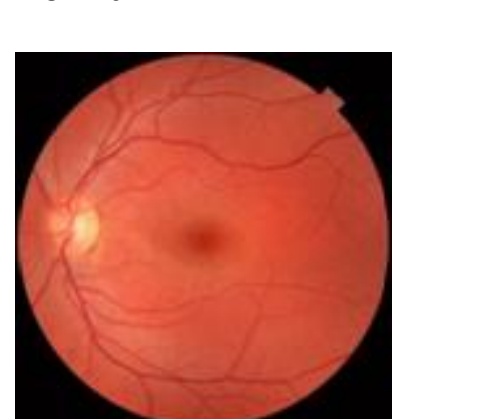 \\
\hline Color vision & $\begin{array}{l}\text { Cannot be performed as } \\
\text { vision is PL+ }\end{array}$ & $\begin{array}{l}\text { Cannot be performed as } \\
\text { vision is PL- }\end{array}$ \\
\hline
\end{tabular}

Visual fields could not be done.

\section{INVESTIGATIONS:}

Blood investigations were normal.Vit-B12 assay is in normal range.

B-Scan, OCT, MRI was normal.

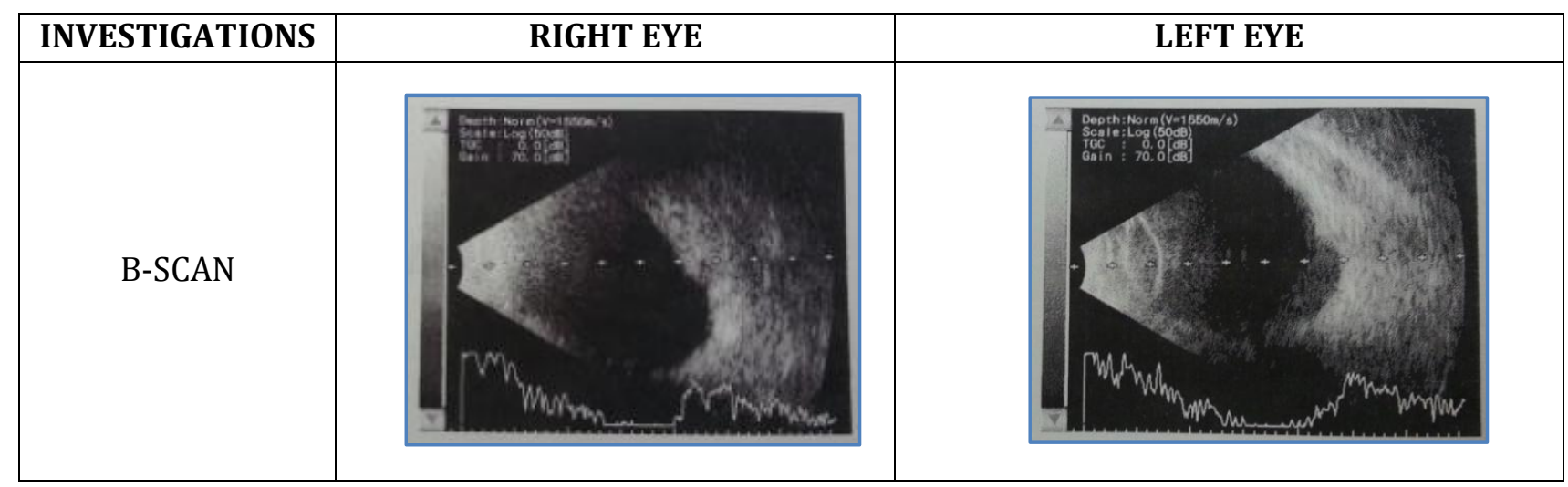




\section{CASE REPORT}

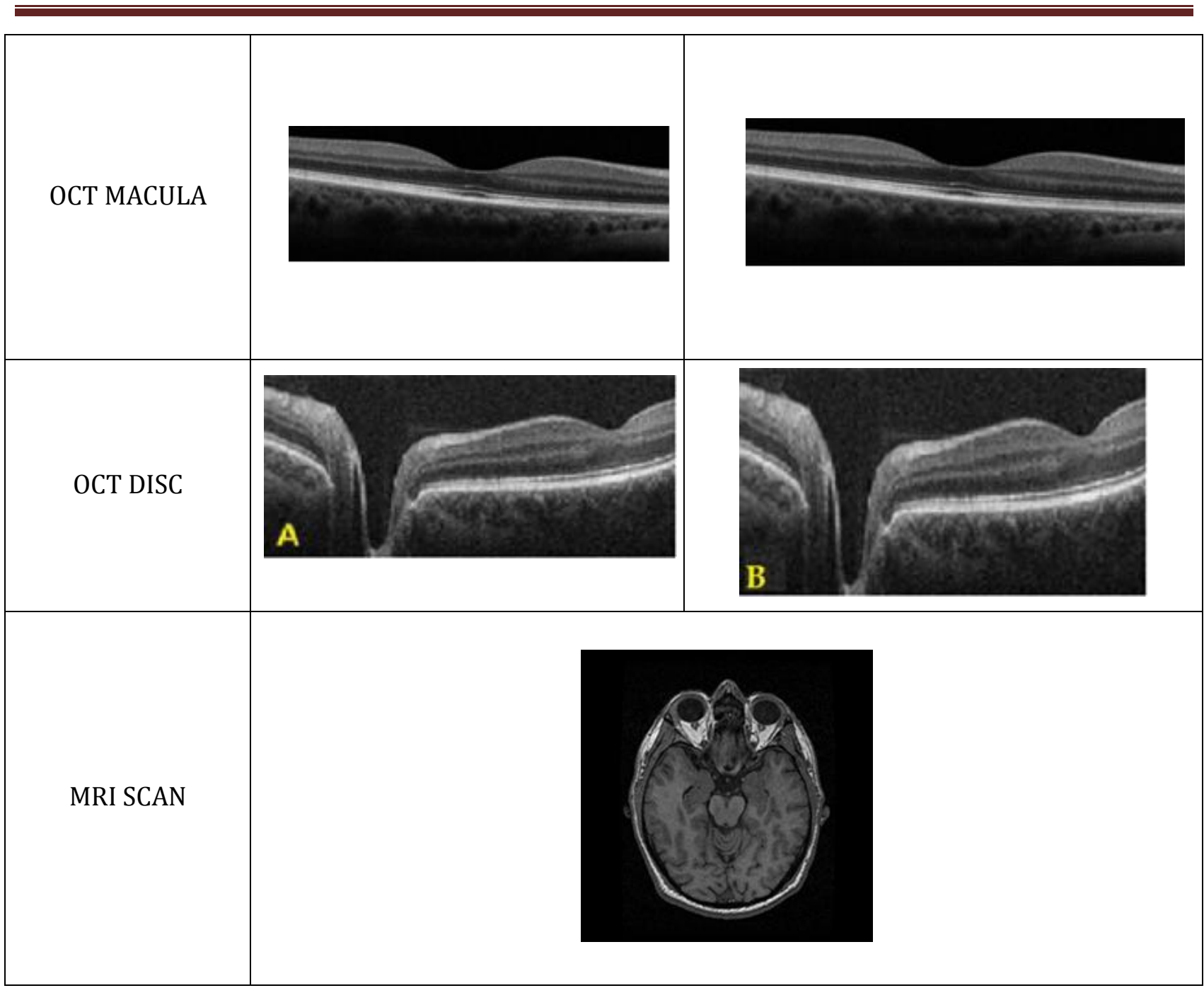

TREATMENT: Patient was treated with intra venous methyl prednisolone $500 \mathrm{mg}$ in $100 \mathrm{ml}$ NS BD for 3 days followed by oral prednisolone $60 \mathrm{mg}$ for 11 days and tapered suddenly in 3 days. ${ }^{2}$

\section{FOLLOW UP:}

\begin{tabular}{|c|c|c|c|}
\hline $\begin{array}{c}\text { After therapy with i.v } \\
\text { methyl prednisolone }\end{array}$ & 2 days later & 2 weeks later & $\mathbf{6}$ Months later \\
\hline Vision in Right Eye & $\begin{array}{c}\text { Counting Fingers } 2 \\
\text { meters }\end{array}$ & $\begin{array}{c}6 / 60 \text { unaided } \\
\text { improving to 6/18p }\end{array}$ & $\begin{array}{c}\text { Best corrected visual } \\
\text { acuity is } 6 / 12 p\end{array}$ \\
\hline Vision in Left Eye & $\begin{array}{c}\text { Counting Fingers } \\
1 / 2 \text { meters }\end{array}$ & $\begin{array}{c}6 / 60 p \text { unaided } \\
\text { improving to } 6 / 24\end{array}$ & $\begin{array}{c}\text { Best corrected visual } \\
\text { acuity is } 6 / 18 p\end{array}$ \\
\hline
\end{tabular}

- Patient was able to identify blue and green color but unable to identify red color.

- VEP showed delay in P100.

- Fundus showed temporal disc pallor of both the eyes. Rest of fundus findings was normal. 

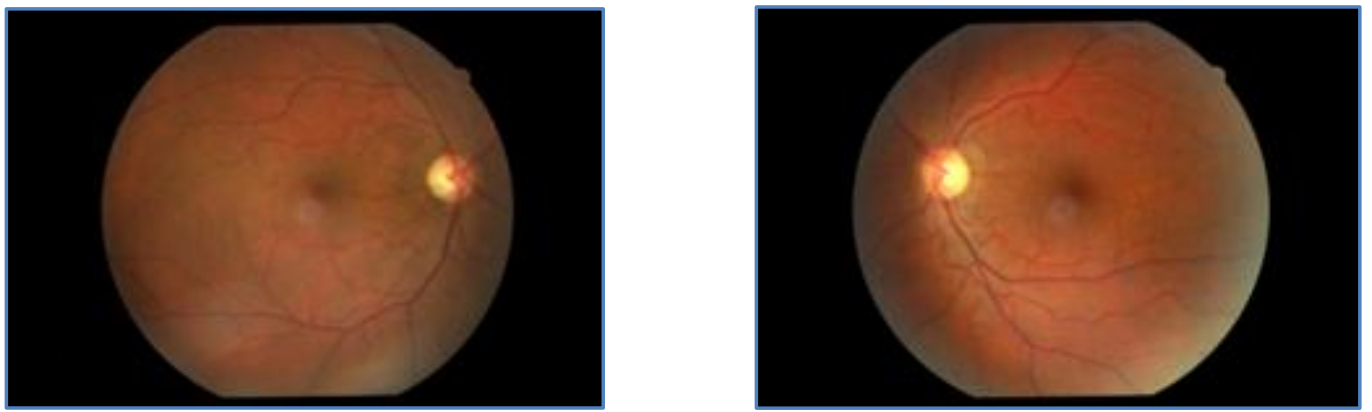

\section{Visual Evoked Potential:}

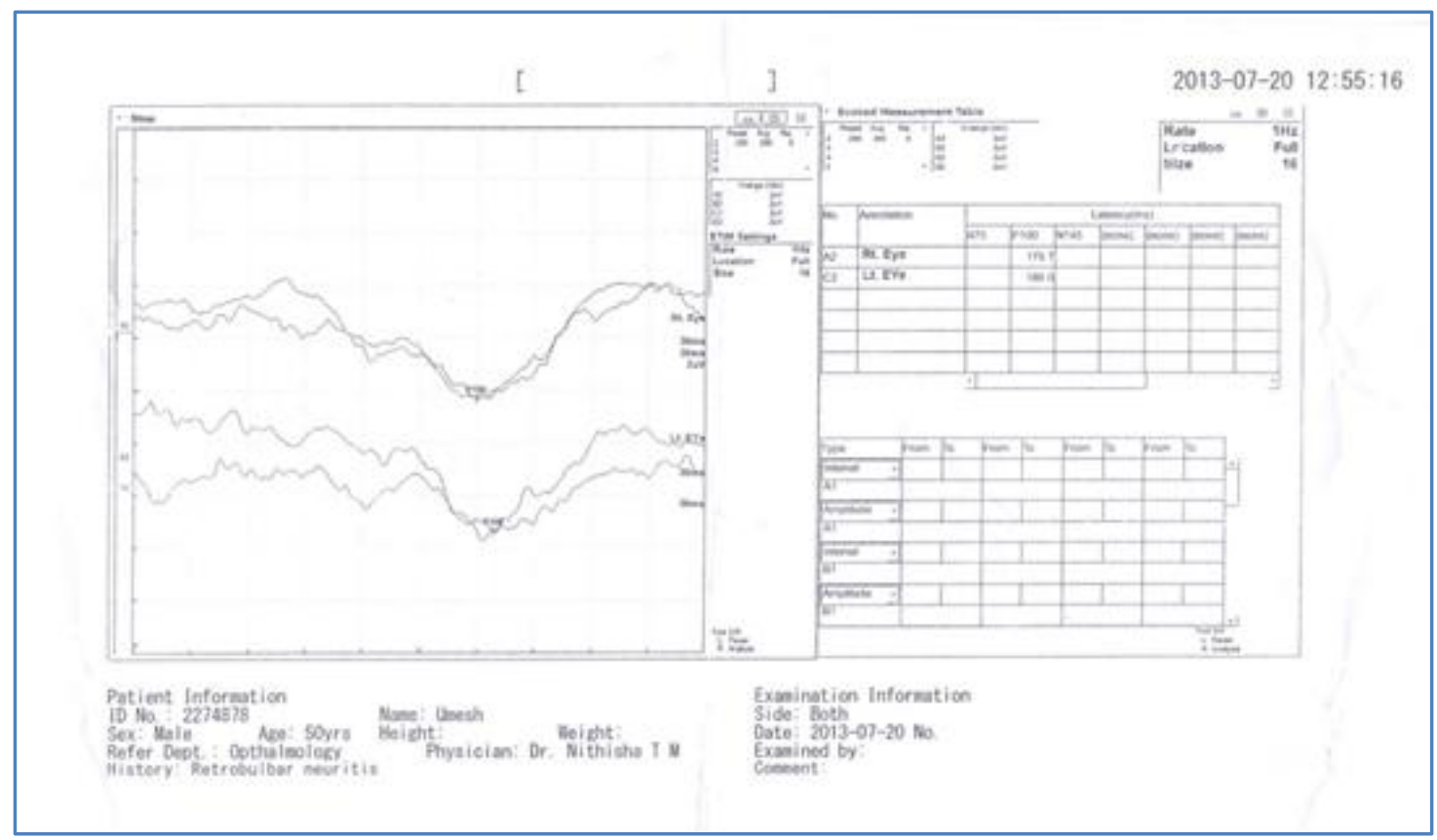

DISCUSSION: Optic neuritis is defined as inflammation of optic nerve, in which optic disc swelling is visible or more commonly, in retro bulbar type of optic neuritis inflammation is posterior to globe without optic disc edema. The etiology of optic neuritis is secondary to demyelination, vasculitis, infection (syphilis, post viral optic neuritis), granulomatous process (wegners granulomatosis, sarcoidosis), or multiple sclerosis. Patient presents with acute or sub-acute vision loss over few days to 2 weeks with recovery starts by one month, majority recover by 2 months. Pain with eye movements is seen in $92 \%$ of cases, decreased color vision, contrast sensitivity, pulfrichs phenomenon of altered perception of motion (due to conduction delay in optic nerve) may be present. 1

On examination decreased visual acuity from $6 / 9$ to no perception of light, RAPD is usually present, optic disc edema is seen in $1 / 3$ of patients. Visual field defects of central, centrocaecal scotomas, altitudinal or nerve fibre bundle defects can be present ${ }^{3,4}$. Blood investigations, vit-B 12 assay, B-scan, OCT, MRI brain to know the cause should be done. Course of disease varies from several days to 2 weeks and recovery is fairly rapid and then slowly improves over 6-12 months ${ }^{2}$. 
Over $75 \%$ patients recover visual acuity to $6 / 9$, however color vision and contrast sensitivity often remain abnormal. Treatment depends on infectious or demyelinating cause and steroids ultimately fastens recovery of vision. ${ }^{2}$

CONCLUSION: In general, optic neuritis is a clinical diagnosis based upon history and examination findings. Fundoscopic examination helps to differentiate between typical and atypical cases of optic neuritis. Diagnostic tests should be done to rule out causes of optic neuritis. ${ }^{5}$ Steroids can reduce recovery time but do not affect long term outcome. Even no perception of light for 1 day got improved with trial of steroids which decreased the recovery time.

\section{REFERENCES:}

1. Golnik Karl, Walsh and Hoyt's Clinical Neurophthalmology: The Essentials. $2^{\text {nd }}$ Edition Wolters Kluwer/Lippincott Williams \& Wilkins, Philadelphia, 2008. p: 146-161.

2. Vimla Menon, Rohit Saxena, Ruby Mishra, Swati Phuljhele. Management of optic neuritis, India J Ophthalmol 2011 Mar-Apr 59(2) 117-122.

3. Jayaraman M, Gandhi RA, Ravi P, Sen P. Multifocal visual evoked potential in optic neuritis, ischemic optic neuropathy and compressive optic neuropathy: India J Ophthalmol 2013 Oct 3.

4. Jiang LB, Shen CY, Chen F, Yan WY, Lai TY, Wang NL. Clinical features of retinal diseases masquerading as retrobulbar optic neuritis. Chin Med J (Eng), 2013, 126(17), 3301-6.

5. Saxena R, Phulijhele S, Menon V, Gadaginamath S, Sinha A, Sharma P. Clinical profile and short-term outcomes of optic neuritis patients in India J Ophthalmol 2013 Nov 11.

\section{AUTHORS:}

1. Nithisha T. M.

2. L. Nanda

3. Shivakumar M.

4. Chenchi Reddy M.

\section{PARTICULARS OF CONTRIBUTORS:}

1. Associate Professor, Department of Ophthalmology, Rajarajeswari Medical College, Bangalore.

2. Senior Resident, Department of Ophthalmology, Rajarajeswari Medical College, Bangalore.

3. Professor and HOD, Department of Ophthalmology, Rajarajeswari Medical College, Bangalore.
4. $2^{\text {nd }}$ Year Post Graduate, Department of Ophthalmology, Rajarajeswari Medical College, Bangalore.

\section{NAME ADDRESS EMAIL ID OF THE} CORRESPONDING AUTHOR:

Dr. Nithisha T. M,

Associate Professor,

Department of Ophthalmology, RRMCH, Bangalore.

E-mail: drchenchireddy@gmail.com

Date of Submission: 05/02/2014.

Date of Peer Review: 06/02/2014.

Date of Acceptance: 24/02/2014.

Date of Publishing: 24/03/2014. 